\title{
Temporal Analysis of the Mangrove Forest at the Mocajuba River Hydrographic Basin-Pará
}

\author{
Juliane da Costa Cavalcante ${ }^{1}$ (D) \\ Aline Maria Meiguins de $\operatorname{Lima}^{1}$ (D) \\ Jéssica Cristina Conte da Silva ${ }^{2}$ (D) \\ Bruno Silva de Holanda ${ }^{1}$ (D) \\ Crislayne Azevedo Almeida ${ }^{1}$ (D)
}

\begin{abstract}
Mangrove forests are ecosystems naturally susceptible to environmental stresses, such as rising sea level and coastal erosion. However, the anthropic stresses, such as real estate speculation, deforestation and water pollution, put at risk this environment's stability, interfering with its balance. The present work's aim is to perform a temporal analysis of the mangrove forest that is a part of the Mocajuba river hydrographic basin and its buffer zone, as well as identifying natural and anthropic stresses to which the mangroves are susceptible. It was verified that the mangrove forest areas presented a substantial reduction between 1984 and 1999, and a small loss between 1999 and 2018. Thus, in the mangrove forest buffer zone, the anthropized areas increased while the forest areas decreased, demonstrating the deforestation in these areas. It can be concluded that the mangrove forest in the study region present a regression.
\end{abstract}

Keywords: Conservation units, spatial analysis, remote sensing.

\section{INTRODUCTION}

The mangrove forest is a phanerophytic community of brackish environment, located at the mouth of rivers and streams that reach the sea, presenting muddy soil (manguito) with the vegetation adapted to salty water (fluvio-marine), such as the red mangrove (Rhizophora mangle), black mangrove (Avicennia sp.) and white mangrove (Laguncularia racemosa) (IBGE, 2012).

The mangrove biome is typically found in coastal environments of tropical and subtropical zones presenting high salinity, muddy soil rich in organic matter, limited oxygen and a diversity of trees and shrubs constantly submerged. This ecosystem provides food and shelter to many species, as well as an income source to the inhabitants of such areas and the surroundings (MATIAS; SILVA, 2017).

Mangrove forests represent $8 \%$ of the Earth's shoreline, amounting to a total of $181,077 \mathrm{~km}^{2}$, from which Brazil has the second largest area with $13,400 \mathrm{~km}^{2}$ of mangrove forest (SPALDING et al., 1997). In the northeast of the
Pará state, mangrove forests cover an area of $2,176.78 \mathrm{~km}^{2}$ (SOUZA FILHO, 2005). These areas are protected by 15 Conservation Units (UC), from which 13 are Extractive Reserves (RESEX) (MMA, 2019).

Even if those areas are legally protected by the Brazilian Law n. 12651/2012 (Brazilian Forest Code), the mangrove forests face constant anthropic impacts, such as substantial crab capture, real estate pressure, and also the land use substitution to develop agriculture and livestock activities. These anthropic threats interfere in the ecosystem's resilience when facing natural impacts, such as climate change, rising sea level and dunes progression over the mangrove areas (CARVALHO; JARDIM, 2019).

The mangrove forest at the Mocajuba river basin is inserted in this perspective, facing threats caused by the expansion of anthropic occupation, such as urban areas, crops and pastures (TELES; PIMENTEL, 2015). Aiming to restrain the expansion of such activities and protect the mangrove areas, the Conservation Units for Sustainable Use were created in the RESEX category, considering that the Mocajuba river basin encompasses a portion of three

\footnotetext{
${ }^{1}$ Universidade Federal do Pará, Programa de Pós-graduação em Ciências Ambientais, Belém, PA, Brasil

${ }^{2}$ Universidade Federal do Pará, Programa de Pós-graduação em Engenharia Civil, Belém, PA, Brasil
} 
of such units: RESEX São João da Ponta (unnumbered decree from 13 December 2002), RESEX Mãe Grande de Curuçá (unnumbered decree from 13 December 2002), and RESEX Mocapajuba (unnumbered decree from 10 October 2014).

Considering the need for studies focused on the behavior of mangrove ecosystems that face anthropic and natural pressures, the present work aims to perform a temporal analysis of the mangrove forest that are a part of the Mocajuba river hydrographic basin and its buffer areas.

\section{MATERIALS AND METHODS}

\subsection{Study area}

The study (Figure 1) area comprises the mangrove forest at the Mocajuba river hydrographic basin, that is a part of the municipalities of São João da Ponta, Curuçá and Terra Alta, located in northeastern Pará, Brazil. The mangrove forest areas are protected by three extractive marine reserves: São João da Ponta, Mãe Grande de Curuçá and Mocapajuba.
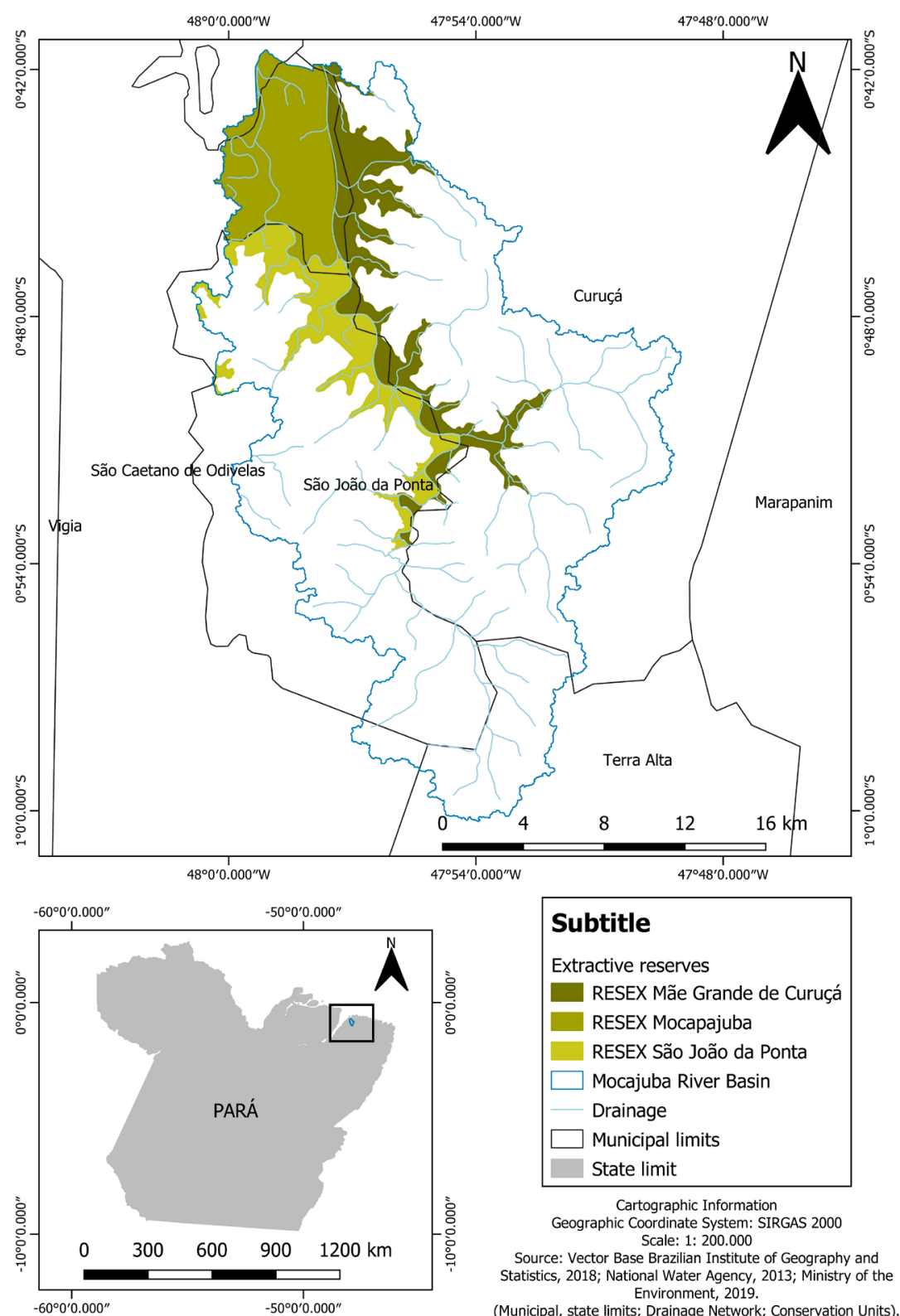

Figure 1. Location of the Mocajuba river hydrographic basin and the extractive reserves. 


\subsection{Platform and data processing}

Google Earth Engine (GEE) platform provides various satellite imagery datasets and other geospatial data that can be exported or processed in the platform. To elaborate land use and cover maps and to quantify mangrove forest areas at the Mocajuba river basin, images were collected from Landsat- 5 TM (LANDSAT/LT05/C01/T1_TOA) for 1984, Landsat-7 ETM+ (LANDSAT/LE07/C01/T1_RT_TOA) for 1999, and Landsat-8 OLI-TIRS (LANDSAT/LC08/C01/T1_RT_TOA) for 2018. The imagery datasets were obtained and processed on the GEE platform.

Using a GEE script, a filter was applied to remove cloud pixels from the imagery datasets between $1^{\text {st }}$ January and 31 December of 1984, 1999 and 2018, with the Quality Assessment (QA) band to exclude pixels that were either too shiny or too dark (clouds and shadows). Lastly, to generate only one image to represent the study years, a median reducer was applied. This methodology intends to generate a final image free of clouds, with "clean" pixels, considering all the images from 1984, 1999 and 2018 (DINIZ et al., 2019; ROSA, 2018).

\subsection{Classification and sampling class}

Using the selected images, the calculation was done for the following spectral indexes:

- Normalized Difference Vegetation Index (NDVI) (eq. 1) uses the red (RED) and near-infrared (NIR) wavelengths (ROUSE et al., 1973).

$$
\mathrm{NDVI}=\frac{\mathrm{NIR}-\mathrm{RED}}{\mathrm{NIR}+\mathrm{RED}}
$$

- Normalized Difference Water (or Moisture) Index (NDWI or NDMI) (eq. 2) is derived from the near-infrared (NIR) and short-wave infrared (SWIR) bands (GAO, 1996).

$\mathrm{NDMI}=\frac{\mathrm{NIR}-\mathrm{SWIR}}{\mathrm{NIR}+\mathrm{SWIR}}$

- Modified Normalized Difference Water Index (MNDWI) (eq. 3) uses green (Green) and short-wave infrared (SWIR) bands (XU, 2006).

$$
\text { MNDWI }=\frac{\text { Green }- \text { SWIR }}{\text { Green }+ \text { SWIR }}
$$

After calculating the spectral indexes, the Random Forest classifier, available at the GEE platform, was used to perform decision-making based on random variables subsets, generating various classifiers groups, such as tree (bootstrap), that is, decision trees arrangement (bagging or bootstrap aggregating) (GISLASON et al., 2005). The imagery spectral bands and spectral indexes generated were used for the decision-making.

The collection of samples started with the classes to be mapped: (1) water, that encompasses all water classes, such as oceans, rivers, natural and artificial lakes, and others; (2) mangrove forest, vegetation influenced by fluvial and marine water (IBGE, 2012); (3) forest formation, dense ombrophilous vegetation, primary or secondary, and also areas in the initial stage of recovery (IBGE, 2012); (4) non-forest, land cover with various anthropic uses, such as urban areas, pasture, agriculture, highways and exposed soil.

The choice to merge the subclasses that constitute "forest formation" and "non-forest" was made to reduce classifier confusion. Furthermore, quantifying forest formation and non-forest classes allows to observe the expansion and regression of natural vegetation and anthropic occupation.

\subsection{Accuracy calculation}

Classifications accuracy was calculated using the Kappa coefficient. In equation $4, \mathrm{~K}$ is the Kappa coefficient, $\sum_{i=1}^{c} x_{i i}$ is the sum of the main diagonal matrix elements; $[c]$ is the number of lines; $\left[x_{i i}\right]$ is the value in line $[i]$ and column $[i] ;\left[x_{i+}\right]$ is the sum of line [ $\left.i\right]$ elements, and $\left[x_{+i}\right]$ is the sum of column [ $\left.i\right]$ elements in the confusion matrix; and $[n]$ is the total number of samples (COHEN, 1960; VALE et al., 2018).

$K a p p a=\frac{n \sum_{i=1}^{c} x_{i i}-\sum_{i=1}^{c} x_{i+} x_{+i}}{n^{2}-\sum_{i=1}^{c} x_{i+} x_{+i}}$

According to the Kappa coefficient, the quality of the classification may be analyzed using the values: 0 (poor); 0.01 - 0.2 (slight); 0.21 - 0.4 (fair); $0.41-0.6$ (moderate); 0.61 - 0.8 (substantial); 0.81 - 1.0 (almost perfect) (LANDIS AND KOCH, 1977; COHEN, 1960).

The points chosen to the accuracy calculation were selected using Random Points tool, a simple random sampling technique available at Qgis 3.6.2 software.

The synthesis of the methodology to quantify mangrove forest areas and generate the land use base: (1) PLATAFORM - Google Earth Engine; (2) DATA - landsat 5, 7 and 8 for 1984, 1999 and 2018, respectively; (3) CLOUDS FILTER - cloud detection and removal; (4) SPECTRAL DATA NDVI, NDWI and MNDWI; (5) CLASSIFIER - Random Forest; (6) CLASSES - water, mangrove forest, forest formation and non-forest; (7) RESULTS - land use base and mangrove forest areas regression and expansion 


\section{RESULTS AND DISCUSSION}

The classifications obtained accuracy values of $0.86,0.92$ and 0.80 for the years 1984, 1999 and 2018, respectively. According to Table 1, it is observed that between 1984 and 1999 there was an increase of 3,48\% in the forest formation class and a decrease of 13,26\% in the non-forest class. Between 1999 and 2018 , there was a reduction of $23,55 \%$ in the forest formation class and a growth of $115 \%$ in the non-forest class.

Table 1. Quantification of mapped classes.

\begin{tabular}{cccc} 
Classes & 1984 & 1999 & 2018 \\
Water & $19.17 \mathrm{~km}^{2}$ & $21.55 \mathrm{~km}^{2}$ & $23.15 \mathrm{~km}^{2}$ \\
\hline Mangrove forest & $62.98 \mathrm{~km}^{2}$ & $59.97 \mathrm{~km}^{2}$ & $59.95 \mathrm{~km}^{2}$ \\
\hline Forest formation & $165.65 \mathrm{~km}^{2}$ & $171.42 \mathrm{~km}^{2}$ & $131.04 \mathrm{~km}^{2}$ \\
Non-forest & $38.74 \mathrm{~km}^{2}$ & $33.60 \mathrm{~km}^{2}$ & $72.40 \mathrm{~km}^{2}$ \\
\hline Total & & $286.54 \mathrm{~km}^{2}$ \\
\hline
\end{tabular}

Source: Author.
These results are similar to the ones found by Teles and França (2014), at São João da Ponta, between 1984 and 1995, which showed a growth in secondary forest areas, and a reduction in anthropic areas (mining and agriculture). Between 1995 and 2004, Teles and França (2014) found a reduction in secondary and primary forest areas and a growth in anthropic areas, although they found a slight increase in the mangrove forest areas, different from what was detected in the present study.

The Mocajuba river basin comprises an area of approximately $406 \mathrm{~km}^{2}$, from which $70 \%$ can be considered as buffer zone, contemplating the $3 \mathrm{~km}$ distance from the boundaries of the Conservation Unit, according to the National Environmental Council resolution n. 428, from 2010 (CONAMA 428/2010). However, the mangrove forest influence area extends beyond the basin's boundaries because of the buffer distance (Figures 2, 3 and 4).

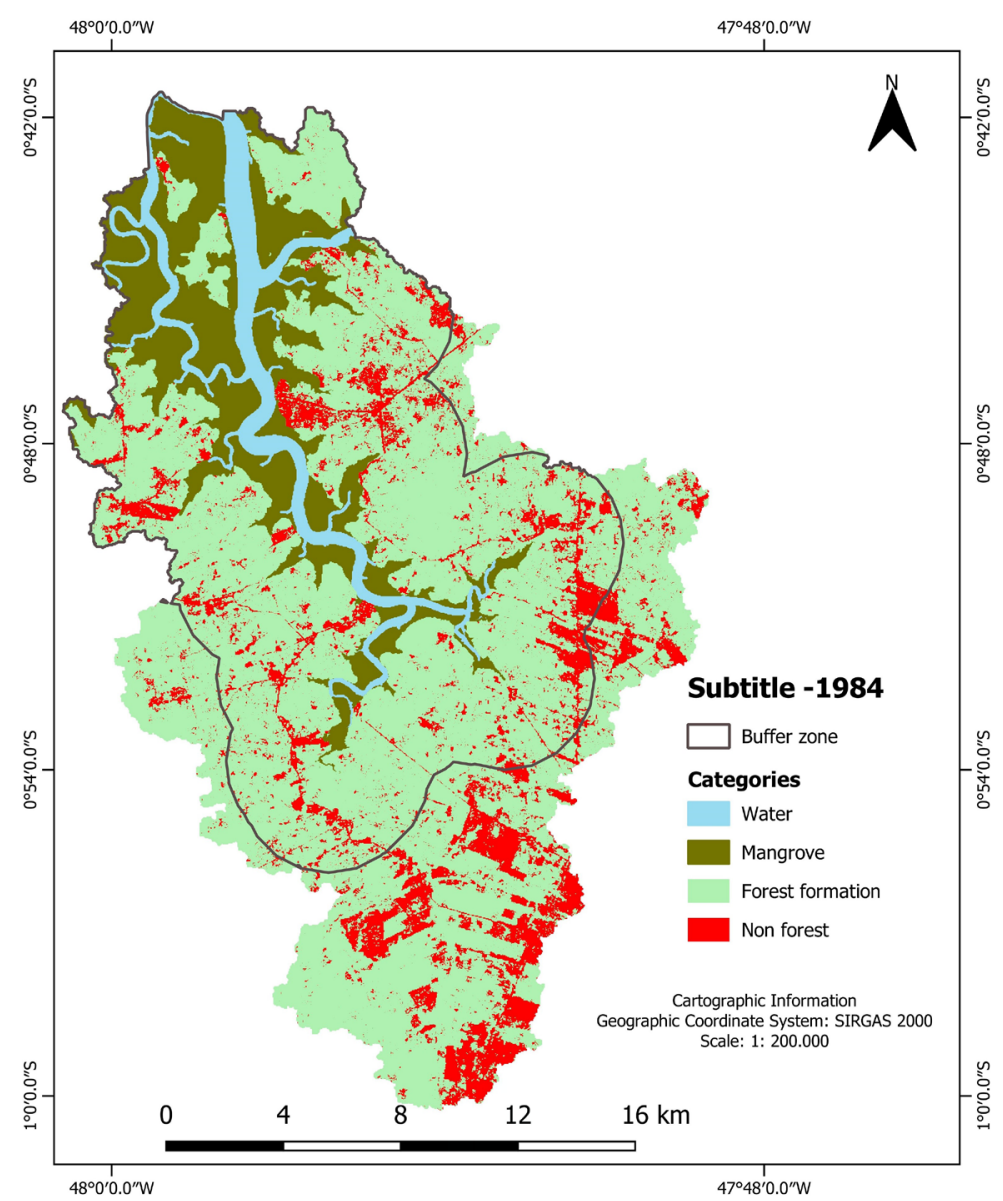

Figure 2. Map of land use and cover on the study area - 1984. 


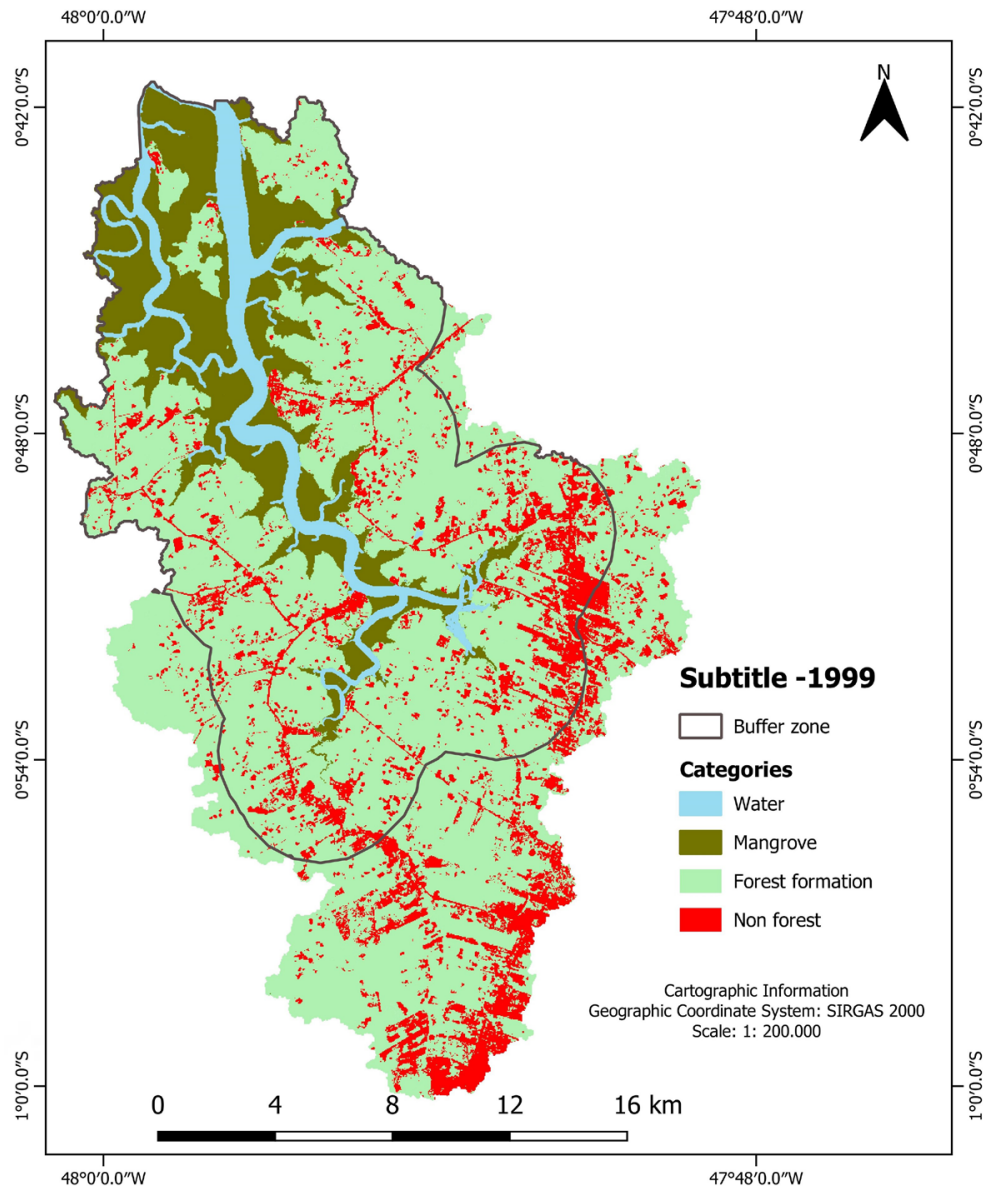

Figure 3. Map of land use and cover on the study area - 1999.

The results show that in 1984 the mangrove forest surroundings were already taken by anthropic activities, even if there was a slight reduction of anthropization in 1999 and a substantial growth seen in 2018. Figures 2, 3 and 4 show the land use dynamic at the study area.

It was observed, during field visits, that mangrove forests in the region face threats due to the expansion of human activities, mainly urban settlements, agriculture and pastures. This was also observed by Teles and Pimentel (2015), who perceived scarce fragments of primary vegetation and extensive areas in various regeneration stages, which indicates that the region has been densely occupied by humans.

The threats in the surroundings of the mangrove forest at the Mocajuba river basin negatively impact the ecosystem's balance. According to Eni et al. (2012), the balance between biotic and abiotic environments safeguard the characteristics of natural environments, such as soil and vegetation aspects. The authors concluded that there is a connection between vegetation and soil parameters, as the vegetation protects the soil from various climate conditions, preventing erosion and maintaining soil moisture, and the soil provides organic matter and nutrients, supporting the vegetation. Thus, the variables are related, sustaining the natural environment's stability and regeneration ability.

In this perspective, studying the composition and development of mangrove forests is essential to connect the ecosystem's response to the existing environmental conditions. Furthermore, it can stablish the similarities of these environment's responses to many natural and anthropic interventions, aiding in predicting other environmental responses to conservation and recuperation actions (SOARES, 1999). 


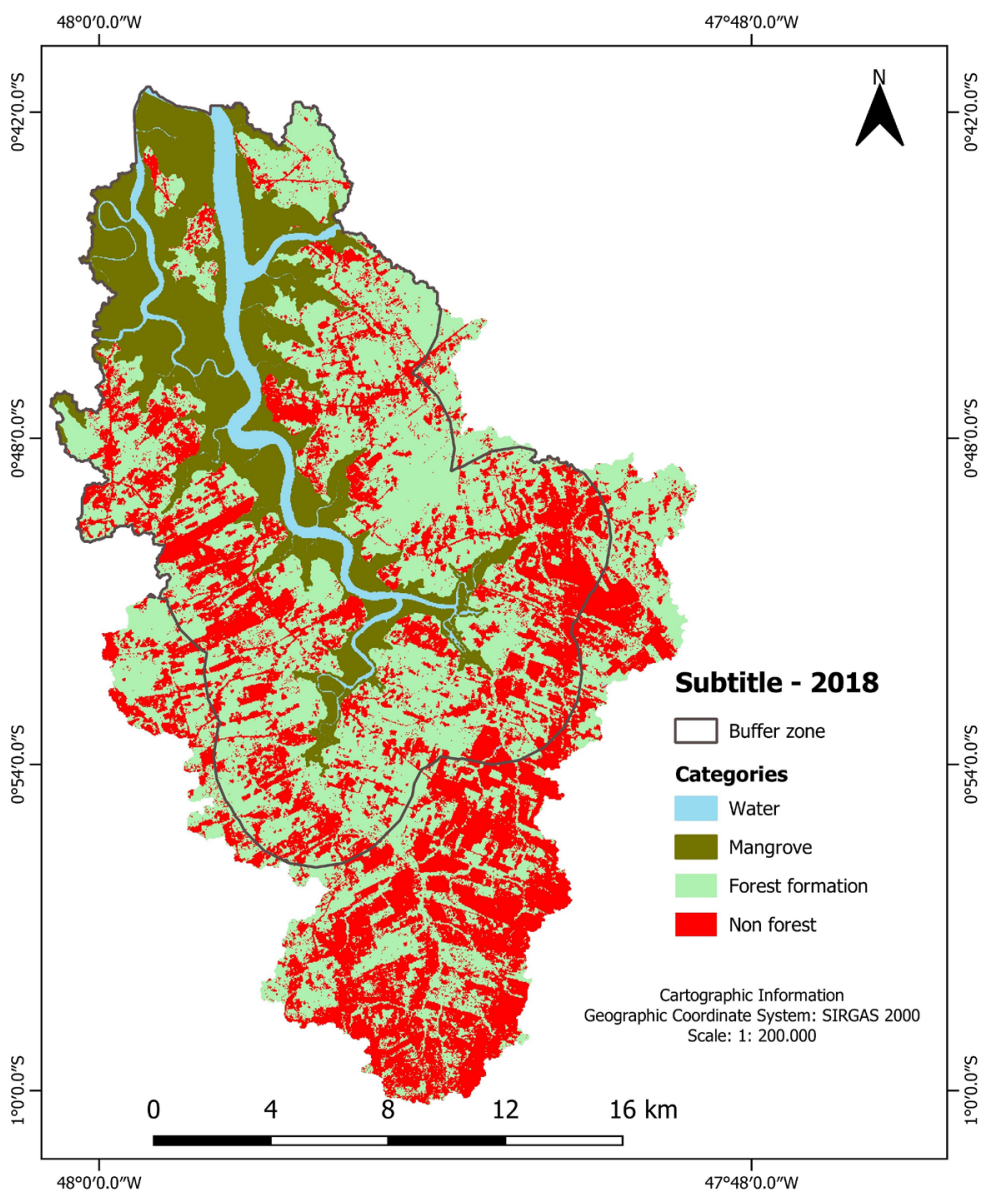

Figure 4. Map of land use and cover on the study area - 2018.

Framework 1 presents secondary data for the composition of flora species of mangrove forests at northeast Pará sites, as well as the environmental and anthropic stresses this ecosystem is susceptible to.

Framework I. Flora composition and structure, environmental and anthropic stresses.

\begin{tabular}{|c|c|c|c|c|}
\hline & $\begin{array}{l}\text { Flora composition and } \\
\text { structure (secondary data) }\end{array}$ & $\begin{array}{l}\text { Environmental stresses } \\
\text { (secondary data) }\end{array}$ & $\begin{array}{l}\text { Anthropic stresses } \\
\text { (secondary data) }\end{array}$ & $\begin{array}{l}\text { Actions } \\
\text { and advices }\end{array}$ \\
\hline \multirow{2}{*}{ 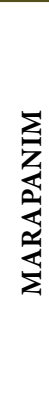 } & $\begin{array}{l}\text { Main tree species: Rhizophora mangle, } \\
\text { Avicennia germinans and Laguncularia } \\
\text { racemosa. Spartina brasiliensis in accretion } \\
\text { zones (LOUBRY; PROST, 2013; PROST } \\
\text { et al., 2013). }\end{array}$ & \multirow{2}{*}{$\begin{array}{l}\text { Erosion processes (sea tide } \\
\text { currents); mangroves buried } \\
\text { by sandbanks; biological } \\
\text { threats on the vegetation } \\
\text { (plagues) (Hyblaea) (PROST } \\
\text { et al., 2013). }\end{array}$} & \multirow{2}{*}{$\begin{array}{l}\text { Artisanal fishing; } \\
\text { urbanization (PROST et } \\
\text { al., 2013) }\end{array}$} & \multirow{2}{*}{$\begin{array}{l}\text { Artisanal fishing inspection } \\
\text { to respect species } \\
\text { reproduction period; } \\
\text { inspection and police } \\
\text { authority in the installment } \\
\text { of urban structures that do } \\
\text { not comply with legislation. }\end{array}$} \\
\hline & $\begin{array}{l}\text { Height: } 10-15 \mathrm{~m} \text {; diameter: } 10-45 \mathrm{~cm} \\
\text { (Rhyzophora mangle); Height: } 10-20 \mathrm{~m} \text {; } \\
\text { diameter: } 40 \mathrm{~cm} \text { (Avicennia germinas); } \\
\text { Height: } 8.5-13 \mathrm{~m} \text {; diameter: } 9 \mathrm{~cm} \\
\text { (Laguncularia racemosa) } \\
\text { (SALES et al., 2009). }\end{array}$ & & & \\
\hline
\end{tabular}


Framework 1. Continuation...

\begin{tabular}{|c|c|c|c|c|}
\hline & $\begin{array}{l}\text { Flora composition and } \\
\text { structure (secondary data) }\end{array}$ & $\begin{array}{l}\text { Environmental stresses } \\
\text { (secondary data) }\end{array}$ & $\begin{array}{l}\text { Anthropic stresses } \\
\text { (secondary data) }\end{array}$ & $\begin{array}{l}\text { Actions } \\
\text { and advices }\end{array}$ \\
\hline 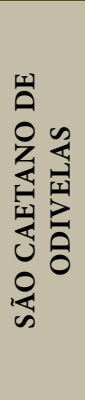 & $\begin{array}{l}\text { Prevailing species found: Avicennia } \\
\text { germinans L. in } 59.6 \% \text { and Rhizophora } \\
\text { mangle L in } 32.06 \% \text {. Less prevailing } \\
\text { species: Avicennia schaueriana Staff and } \\
\text { Leech; Laguncularia racemosa Gaertn } \\
\text { (PROST et al., } 2013 \text { ). } \\
\text { Diameter: } 17.5-22.5 \mathrm{~cm} \text { (Rhyzophora } \\
\text { mangle), considered younger forest; } \\
\text { Diameter: } 17.5-32.5 \mathrm{~cm} \text { (Rhyzophora } \\
\text { mangle), considered stable forest } \\
\text { (RIBEIRO JÚNIOR, } 2017 \text { ). }\end{array}$ & $\begin{array}{l}\text { Erosion processes (sea tide } \\
\text { currents); mangroves buried } \\
\text { by sandbanks; biological } \\
\text { threats on the vegetation } \\
\text { (plagues) (Hyblaea) (PROST } \\
\text { et al., 2013). }\end{array}$ & $\begin{array}{l}\text { Real estate speculation } \\
\text { and solid waste littering } \\
\text { (PINHEIRO, 2014). }\end{array}$ & $\begin{array}{l}\text { Restraints on the } \\
\text { implementation of real } \\
\text { estate developments at } \\
\text { Permanent Preservation } \\
\text { Areas (mangrove forests } \\
\text { and riparian vegetation); } \\
\text { inspection and establishment } \\
\text { of a waste collection system } \\
\text { to serve the local population. }\end{array}$ \\
\hline
\end{tabular}

Rhyzophora sp. (red mangrove), Avicennia $s p$. (black mangrove), Laguncularia sp. (white mangrove) and Acrostichum sp. (mangrove fern) (FRANÇA et al., 2016).
Erosion processes (FRANÇA et al., 2016). small livestock herds (FRANÇA et al., 2016).
Extractive activities, crops,

Environmental education focused on the local population to encourage sustainable agriculture.

Restraints and inspection on the implementation of real estate developments so they comply with environmental legislation; police authority on areas with inordinate settlements at the mangrove forest and riparian vegetation.

Rhizophora mangle, Rhizophora racemosa Rising sea level, advancing Predatory techniques and Inspection to respect aquatic Avicennia germinans (CARVALHO; dunes over the mangrove JARDIM, 2017). forest intensive shellfish capture; species' reproduction mangrove forest cut for period; environmental wood (CARVALHO; education to encourage JARDIM, 2019).

Solid waste littering, sewage Inspection of domestic disposal, deforestation, sewage treatment and intensive shellfish capture, solid waste destination to real estate speculation, comply with environmental tourism, roads construction legislation,

and housing allotments environmental studies to at the Biological Reserve implement projects focused (CARVALHO; JARDIM, 2019; on social and environmental MENDES, et al., 2013). impacts mitigation.

Solid waste littering, sewage Rhizophora mangle (75\%), Avicennia
germinans $(23 \%)$ and Laguncularia racemosa Gaertn (2\%) (CARVALHO; JARDIM, 2017; BASTOS; LOBATO, 1996).

Height: $9.5 \mathrm{~m}$; diameter: $21.60 \mathrm{~cm}$ temperature in dry and wet seasons (MENDES, et al., 2013 CARVALHO; JARDIM, 2019).

(CARVALHO; JARDIM, 2017).

Shoreline erosion (recession disposal, deforestation, of 150 to $200 \mathrm{~m}$ over the intensive shellfish capture and decade) (MENDES et al., sand extraction for construction 2013)

sites (CARVALHO; JARDIM, 2019; MENDES et al., 2013).
Inspection to identify sewage disposal; respect aquatic species' reproduction period; identification of illegal activities.
Environmental studies to implement projects focused
Rhizophora mangle and Avicennia germinans (SEIXAS et al., 2006).

- Height: 8.6 - $11.3 \mathrm{~m}$; diameter: $10-45 \mathrm{~cm}$ (Rhyzophora mangle).

- Height: 10.5 - $11.9 \mathrm{~m}$; diameter: $40 \mathrm{~cm}$ (Avicennia germinas) (SEIXAS et al., 2006).
Shoreline erosion (recession of $50 \mathrm{~m}$ observed in one year 1998/1999); changes on the coastal vegetation due to sand banks advancing over mangrove forests (SOUZA FILHO 2013).
Road construction; on mitigation of social and disruption of drainage environmental impacts; networks where roads serve protection of mangrove as barriers for the sea tides forests and riparian vegetation of beaches; solid waste settlements; inspection of 2013). and solid waste destination flow; inordinate occupation by banning new anthropic littering (SOUZA FILHO domestic sewage treatment to comply with environmental legislation. 
Several species observed at the Mocajuba river basin are common in mangrove forest environments, according to Framework 1, such as Rhyzophora mangle and Avicennia germina.

As well as the mentioned sites, the mangrove forests located on the whole study area are exposed to various anthropic stresses, threatening their stability. According to Prost et al. (2013) anthropic stresses are site specific, so they have low intensity, frequency and magnitude. Therefore, these stresses do not affect the energy input and do not cause significant alterations on the structure and diversity that may lead to mangrove forest regression.

In contrast, stresses are localized interventions that influence species behavior when facing changes on the natural environment. An example is the case of the highway PA 458 (Bragança - Ajuruteua) whose construction was started in 1973 opening a road $45 \mathrm{~km}$ long from the center of Bragança to Ajuruteua beach, covering a part of the mangrove forest on its way. Currently this forest is slowly recovering and adapting, but the crab population was severely reduced, which affected the people who traditionally captured them as an economic subsistence activity (OLIVEIRA, HENRIQUE, 2018).

In the location where the basin land cover transition from mangrove forest to mainland, there is secondary vegetation and exposed soil. The secondary vegetation area might be a way for the forest species to adapt when facing environmental changes, that is, as a way to maintain the balance, mangrove species, which occupied these areas before and were suppressed by anthropic intervention, were replaced through secondary succession. According to Bastos and Lobato (1996), anthropic stresses cause long term responses that result in alterations and losses in the vegetation structure at certain environments.

On the other hand, exposed soil areas interfere in the sediments transport and in the water contribution from the basin to the river's mouth. Mochel et al. (2013), in the study of mangrove forest at São Luís, Maranhão, conclude that deforesting the terrestrial ecosystems surrounding the mangrove swamps intensify the erosion process, increasing the sediments deposition on the swamps. In this situation, indirect impacts, such as mainland deforestation, might negatively affect the mangrove forests, as is the case of the buffer zone at the Mocajuba river basin, where $25 \%$ of the area is occupied by anthropic activities (Table 1).
Table 2. Mangrove forest transition matrix.

\begin{tabular}{|c|c|c|c|}
\hline & 1984 & 1999 & 2018 \\
\hline \multirow{2}{*}{ Total mangrove forest $\left(\mathrm{km}^{2}\right)$} & 62.98 & 59.97 & 59.95 \\
\hline & 1984 - 1999 & $1999-2018$ & $1984-2018$ \\
\hline $\begin{array}{l}\text { Unaltered mangrove } \\
\text { forest }\left(\mathbf{k m}^{2}\right)\end{array}$ & 59.51 & 57.53 & 58.56 \\
\hline Regression (km ${ }^{2}$ ) & 3.475 & 2.44 & 4.42 \\
\hline Mangrove forest to Water & 1.9 & 1.94 & 3.6 \\
\hline $\begin{array}{l}\text { Mangrove forest to Forest } \\
\text { formation }\end{array}$ & 1.56 & 0.48 & 0.8 \\
\hline $\begin{array}{l}\text { Mangrove forest to } \\
\text { Non-forest }\end{array}$ & 0.015 & 0.02 & 0.02 \\
\hline Expansion $\left(\mathrm{km}^{2}\right)$ & 0.46 & 2.42 & 1.39 \\
\hline Water to Mangrove forest & 0.12 & 0.48 & 0.28 \\
\hline $\begin{array}{l}\text { Forest formation to } \\
\text { Mangrove forest }\end{array}$ & 0.3 & 1.93 & 1.05 \\
\hline $\begin{array}{l}\text { Non-forest to Mangrove } \\
\text { forest }\end{array}$ & 0.04 & 0.01 & 0.06 \\
\hline
\end{tabular}

Source: Author.

Considering this perspective, even if the anthropic stresses are considered site specific, human's long-term interferences over the environment might make it difficult for mangrove forests to survive, affecting their adaptation and responses when faced with natural impacts. That was proved by Thomas et al. (2017) in the quantification of mangrove forest areas between 1996 and 2010 in South, Central and North America, Middle East, Southeast Asia and Oceania. The mangrove forest's area loss caused by anthropic action totalized $38 \%$, from which $16 \%$ was due to agriculture. The untouched mangrove forest area was $45 \%$ of the total global mangrove forest area.

Aside from anthropic impacts, oscillations on the natural environment also interfere on the mangrove forests survival. According to Charron et al. (2013), the mangrove forests evolution is intrinsically dependent on shoreline morphosedimentary modifications. The alternance of erosion processes and coastal progradation is followed by the progression and regression of mangrove forests that face the sea. In contrast, according to Bezerra et al. (2013), climate change and, consequently, rising sea level directly affect mangrove forests, with the extension of such impacts depending on local characteristics. Therefore, it is not possible to state that the variations in the Mocajuba river mangrove forests are caused only by the expansion of human settlements without taking into consideration the natural conditions that also affect these environments. 
Considering the environmental and anthropic impacts to which the mangrove forests are susceptible, the Mocajuba river basin's mangrove forest suffered modification on its extension between 1984 and 2018 (Figure 5). As shown in Table 2, between 1984 and 1999 the region suffered a loss, and between 1999 and 2018, the decrease was less significant.

According to Table 2, from the total area of mangrove forests in the basin in 1984, 94.49\% remained until 1999, resulting in an alteration of 5.51\%. In the transition between 1999 and 2018 , from the total area remaining from 1984, approximately
95.93\% remained, thus $4.07 \%$ suffered alterations. This way, summing the numbers from 1984 until 2018, approximately $10 \%$ of the total area of mangrove forests suffered some type of transformation. The map demonstrates that part of this alteration $(6.6 \%)$ implicates that those areas became part of the riverbed because they are related to deforestation actions, which caused riparian erosion and an increase in the river cross-section. The remaining 3.4\% correspond to a definitive alteration, either to secondary vegetation or non-forest areas.

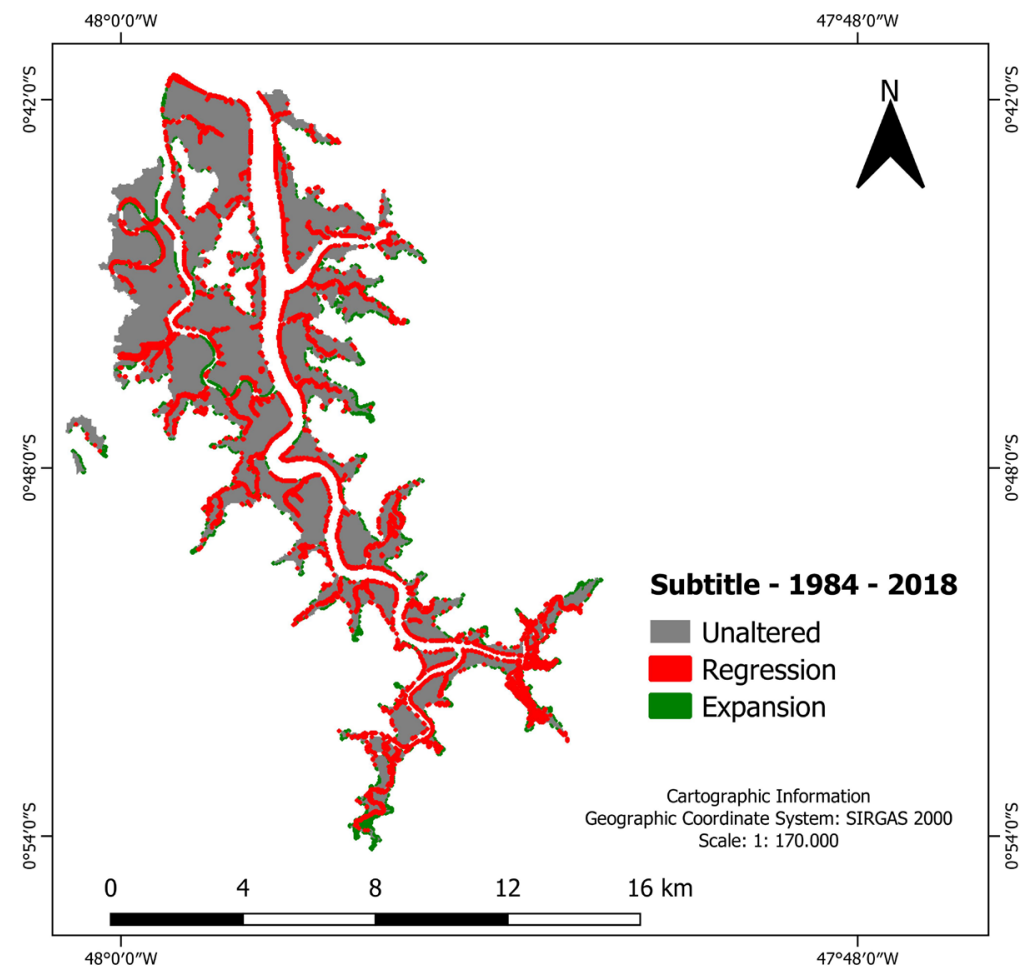

Figure 5. Regression and expansion of mangroves between 1984 and 2018.

This result diverges from other authors, such as Diniz et al. (2019), who observed a regeneration tendency on Brazilian mangrove forests over the last three decades. However, when performing a timeframe comparison, the authors observed a growth on mangrove forest areas between 1985 and 1999, and a small reduction between 1999 and 2018, that last one similar to the result found on the present study. Between 1986 and 1995, Faure (2013) observed an increase on mangrove forest areas at São Caetano de Odivelas and Marapanim, Pará. In addition, Nascimento Júnior et al. (2013) also observed an increase on mangrove forest areas between 1996 and 2008, in the states of Pará and Maranhão. In Table 2, it is noted that the mangrove forest areas are expanding in the Mocajuba river basin, even if the expansion rates are lower than the regression rates.

Thomas et al. (2018) researched 16 areas in an attempt to represent the global range of mangrove forests. They observed a growth tendency between 1996 and 2010 mostly at the mangrove forest in Bragança, Pará, but also a reduction tendency at the mangrove forests in São Luís, Maranhão, and in the state of Amapá on the same years.

Thus, it is possible to understand that the dynamic of mangrove forests changes depending on the region, the natural characteristics, the environment's oscillations, the 
anthropic interferences and, mostly, the forest's resilience and behavior when facing these issues.

Once more analyzing Table 2, it is observed that the expansion and regression of mangrove forests occurred mainly with the classes Water and Forest formation. That is, the mangrove forests substituted or were substituted mostly by Water or Forest. The variations between Mangrove forest and Non-forest were inferior, concluding that the anthropic settlements are not yet interfering considerably in the survival of mangrove forests in the region and that the Extractive Reserves are protecting mangrove forests from the expansion of anthropization.

According to Table 2, the dynamic of the mangrove forests at the Mocajuba river basin tends to regression. Therefore, mangrove forest areas that suffered regression were bigger than the areas regenerated on each of the three studied years. The areas that receded were mainly replaced by erosion processes (Mangrove forest to Water) and changes in the natural environment (Mangrove forest to Forest formation).

The mangrove forest areas that became secondary forest (Table 2) might have suffered anthropic or natural impacts, changing the ecosystem's characteristics and, consequently, inhibiting the survival of mangrove species and creating an environment suitable for secondary succession.

Rovai et al. (2012) concluded that restoring mangrove species into impacted areas is compromised by residual stresses, therefore sowing mangrove species might be ineffective if the local characteristics were not taken into consideration. In this case, the consequences of impacting mangrove forests may run deeper, making it difficult to ensure their survival and favoring their substitution to more resilient species, such as the secondary forests at the Mocajuba river basin.

The fact that water invaded areas that previously were mangrove forests proves the occurrence of erosion processes in the basin, as well as in anthropized areas near rivers and mangrove forests. Faure (2013) also claims that this region is characterized by small erosion sites associated with anthropic factors. Likewise, the rising sea level causes the displacement of the influence area of sea tides, flooding and eroding the mangrove forest areas (GILMAN et al., 2006).

According to Prost et al. (2013), at the Marapanim and São Caetano de Odivelas mangrove forests were observed the same patterns for succession gradients as the ones at the Mocajuba river basin. The succession gradient called "Stick Pattern" (Padrão Paliteiro) is specific to areas eroded by the sea tides, presenting adult species of Avicennia sp. and Rhyzophora mangle on the boundaries, because all other younger mangrove trees were affected and removed by erosion (Figure 6).

In contrast, the rising sea level also favors the migration of mangrove trees towards the mainland in case there are no barriers to their colonization (GILMAN et al., 2006), such as the water and secondary forest areas that were substituted for mangrove forests. In the same way, according to Faure (2013), the sediments carried by the Mocajuba river tend to be partially imprisoned on the estuarine perimeter, forming fine sand deposits, small barriers and sand islands, where the mangrove trees can migrate to, representing a specific vegetation succession.

Similar to the "Stick Pattern" observed by Prost et al. (2013), the study area also presented the "Stair Pattern" (Padrão Escada) (Figure 7), characterized by mixed trees of Rhyzophora mangle, Avicennia germinas and other species, and associated with mangrove forest's progradation zones where there is fine sediments accumulation and, consequently, the establishment of tidal muddy plains.

The mangrove forest areas substituted with non-forest areas were very small if compared with other classes. However, it is a change that requires attention due to the fragility of mangrove forests when facing anthropic interventions, as well as the forest's potential to recover with favorable environmental factors, as explained before. 


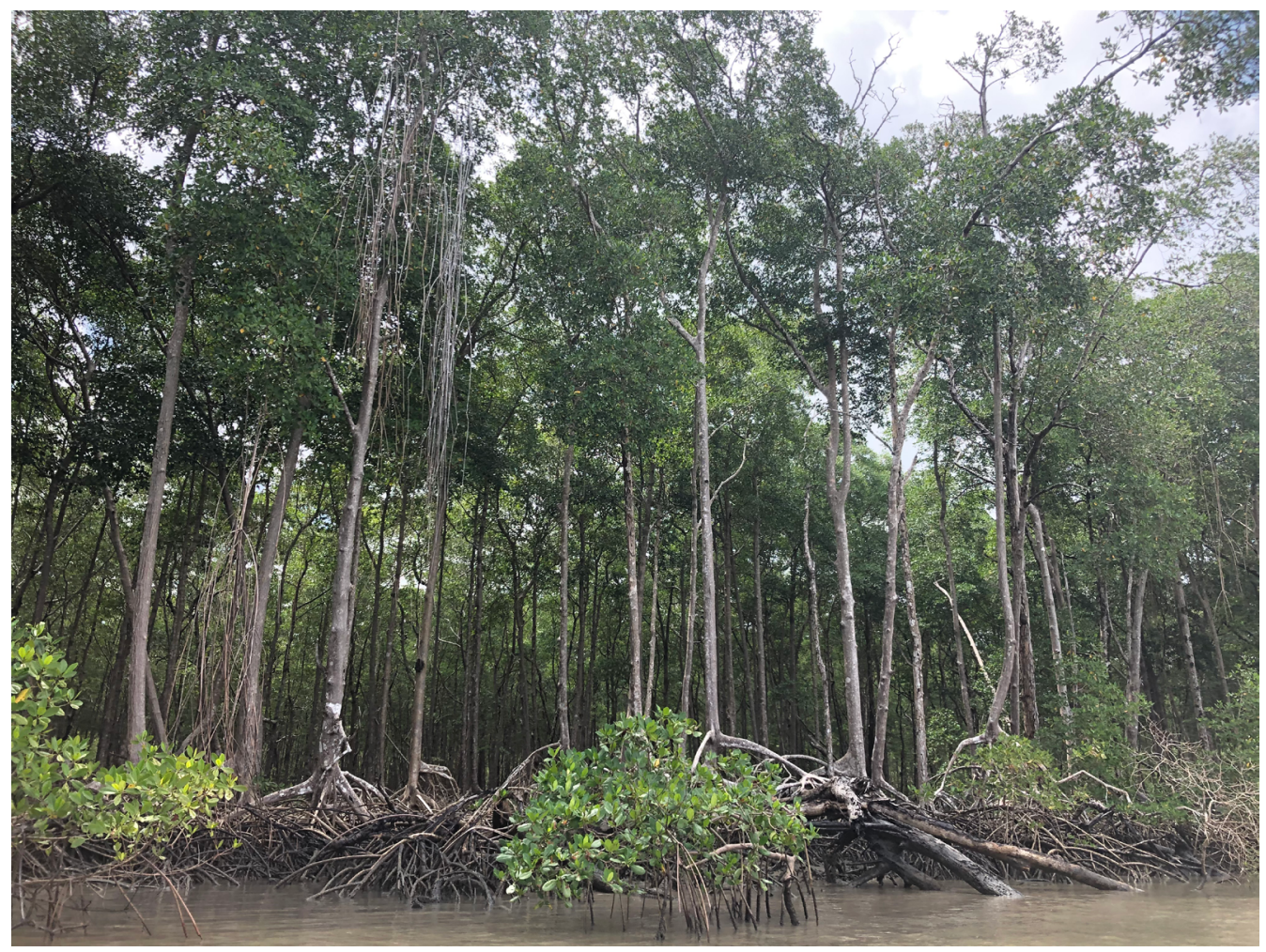

Figure 6. Stick pattern (paliteiro).

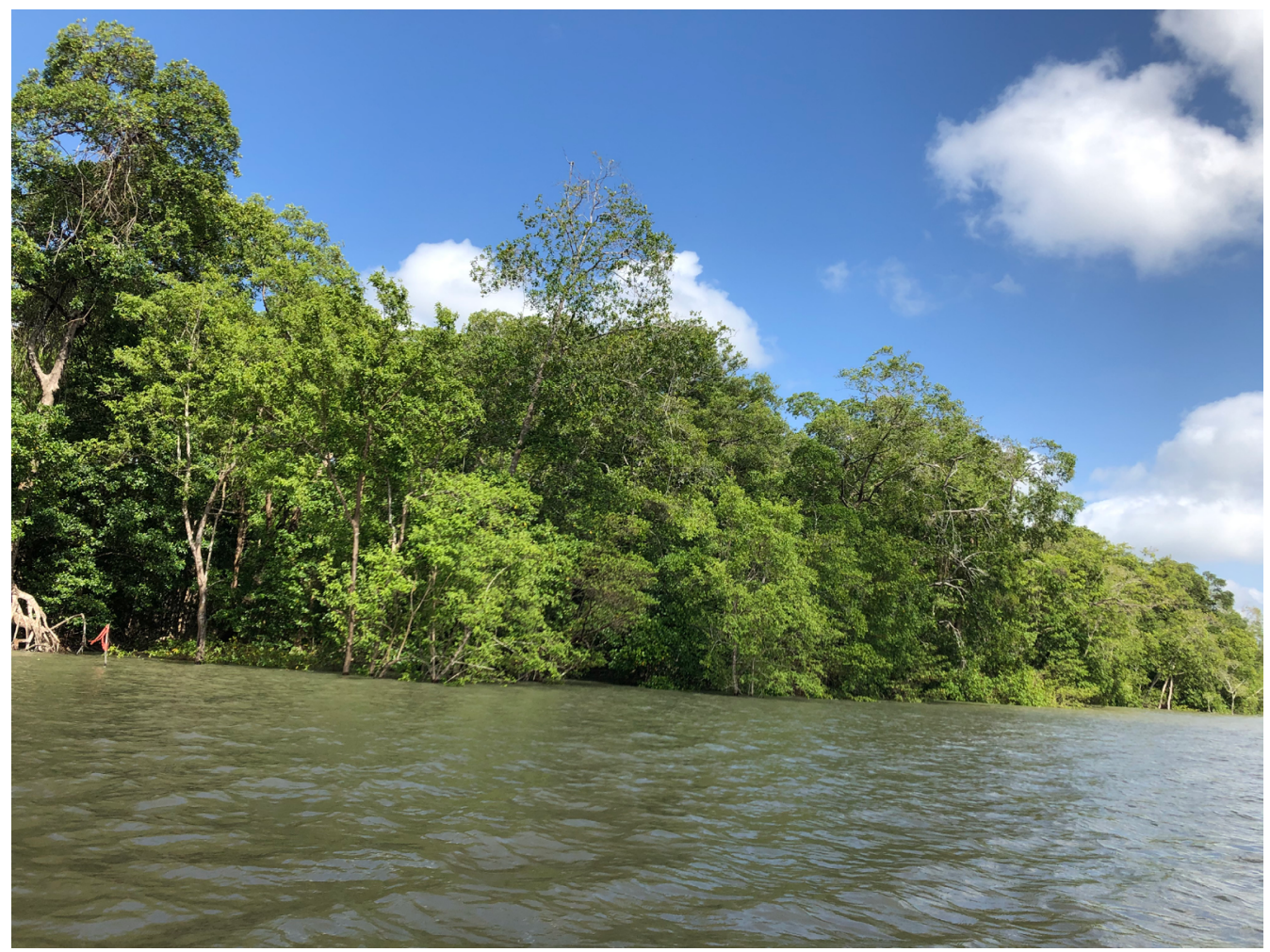

Figure 7. Stair pattern (escada). 
Matias and Silva (2017) performed the temporal analysis of mangrove forests at the south of Alagoas between 2004 and 2016, noting expansion and regression in various areas. Mangrove forests protected by Conservation Units and in areas with higher saltwater input expanded, while mangrove forests pressured by anthropic activities regressed. Thus, if the Conservation Units administrations do not initiate the actions to ensure conservation, management and sustainability on the extractive reserves, the mangrove forests will continue to have their survival threatened.

Summarizing, mangrove forests in the Mocajuba river basin had a regression behavior due to both natural and anthropic factors aforementioned. The Extractive Reserves (RESEX), created to contain the expansion of human occupation and protect mangrove forests, are fulfilling their objectives. As observed, a few mangrove forest areas were replaced by anthropized areas. However, the area considered as Buffer Zone is anthropized, which might negatively interfere in the mangrove forests long term dynamic.

Also, the RESEXs do not have a Management Plan, which difficult initiatives to conserve and manage these Conservation Units (UC), aiding the anthropization stress over the mangrove forests in the whole basin and in the buffer zone.

\section{CONCLUSION}

The results show that the mangrove forest lost area between 1984 and 2018, presenting a regression behavior. However, this forest has a recovery potential (expansion), but with a lower intensity compared to the suppression (regression).

The region's mangrove forest is susceptible to human intervention, such as urban settlements expansion, agriculture and pasture areas. Those encompass the nonforest class, that presented an increase between 1984 and 2018 on the RESEX buffer zone. Besides the anthropic stresses, the mangrove forest is also subject to natural stress, such as rising sea level.

The changes in mangrove forest areas occurred mainly converting them to Water and Forest formation, considering that a greater amount of water substituted or was substituted by mangrove forests. The opposite occurred between the classes Mangrove forest and Non-forest, concluding that the expansion of anthropic activities in the basin still interfere very little with the mangrove forest dynamics, and that area transformations in the region happen mainly between mangrove forests, water and other forest areas.
Approximately $90 \%$ of the total mangrove forest areas in the basin remained unaltered during the period studied by the present work. Around $10 \%$ of the mangrove forest areas were altered, becoming part of riverbeds due to erosion processes, or suffered changes in their structure when occupied by other secondary vegetation and by non-forest areas.

In this context, the mangrove forests located at the northeast of the Pará state are susceptible to conditions that come from natural changes, such as coastal erosion, and to anthropic stress. That stress puts a pressure on the stability of the mangrove forest at the Mocajuba river basin, where the anthropic activities may affect this ecosystem's long-term resistance when facing natural stresses.

Therefore, the purpose of the Marine Extractive Reserves, to protect and conserve mangrove forests that face the expansion of anthropic activities, is being fulfilled. Even with the expansion of these activities along the main river in the Mocajuba river basin, the RESEX are protecting the mangrove forests borders. However, the Buffer Zones are occupied by anthropic activities, which, if extended to the whole basin, might interfere in the mangrove forests dynamic.

\section{SUBMISSION STATUS}

Received: 02 sep. 2020

Accepted: 16 nov. 2020

Associate editor: Rodrigo Studart Corrêa (1)

\section{CORRESPONDENCE TO \\ Juliane Costa Cavalcante}

Universidade Federal do Pará, Rua Augusto Corrêa, 01, CEP 66075-110, Belém, PA, Brasil

e-mail: julianecosta63@gmail.com

\section{REFERENCES}

Almeida SS. Estrutura e florística em áreas de manguezais paraenses: evidências da influência do estuário amazônico. In: Boletim do Museu Paraense Emílio Goeldi, editor. Série Ciências da Terra. Belém: Pará; 1996.

Bastos MNC, Lobato LCB. Estudos fitossociológicos em áreas de bosque de mangue na praia do Crispim e Ilha de Algodoal - Pará. In: Boletim do Museu Paraense Emílio Goeldi, editor. Série Ciências da Terra. Belém: Pará; 1996.

Bezerra DS, Amaral S, Kampel M. Impactos da elevação do nível médio do mar sobre o ecossistema manguezal: a contribuição do sensoriamento remoto e modelos computacionais. Ciência e Natura 2013; 35 (2): 152-162.

Brasil. Lei no 12.651, de 25 de maio de 2012. Código Florestal Brasileiro. Diário Oficial da União, Brasília, DF (2012 mai. 28); Sec. 102: 1 - 168 . 
Carvalho EA, Jardim MAG. Composição e estrutura florística em bosques de manguezais paraenses, Brasil. Ciência Florestal 2017; 27 (3): 923-930

Carvalho EA, Jardim MAG. Usos sociais do manguezal por comunidades tradicionais no estado do Pará, Brasil. Biota Amazônia 2019; 9 (2): 43-46.

Charron C, Panechou K, Huynh F, Gardel AA. Gestão do meio costeiro: abordagem espacial e multidisciplinar do ambiente litoral amazônico. In: Prost MTRC, Mendes AC, editors. Ecossistemas Costeiros: Impactos e Gestão Ambiental. Museu Paraense Emílio Goeldi. Belém: Pará; 2013.

Cohen J. Coefficient of agreement for nominal scales. Educational And Psychological Measurement 1960; 20 (1): 37-46.

Diniz C, Cortinhas L, Nerino G, Rodrigues J, Sadeck L, Adami M, Souza Filho PWM. Brazilian mangrove status: three decades of satellite data analysis. Remote Sensing 2019; 11 (7): 808-826.

Eni DD, Iwara AI, Offiong RA. Analysis of soil-vegetation interrelationships in a south-southern secondary forest of Nigeria. International Journal of Forestry Research 2012; 2012: 1-8.

Faure JF. Análise multitemporal da dinâmica espacial de manguezais em São Caetano de Odivelas, Costa Nordeste do Pará, Brasil. In: Prost MTRC, Mendes AC, editors. Ecossistemas Costeiros: Impactos e Gestão Ambiental. Museu Paraense Emílio Goeldi. Belém: Pará; 2013.

França CF, Pimentel MAS, Neves SCR. Estrutura paisagística de São João da Ponta, Nordeste do Pará. Geografia Ensino \& Pesquisa 2016; 20 (1): 130-142.

Instituto Brasileiro de Geografia e Estatística. Manual técnico da vegetação brasileira: sistema fitogeográfico, inventário das formações florestais e campestres, técnicas e manejo de coleções botânicas, procedimentos para mapeamentos. Rio de Janeiro; 2012.

Gao BC. NDWI - A Normalized Difference Water Index for remote sensing of vegetation liquid water from space. Remote Sensing of Environment 1996; 58: 257-266.

Gilman EL, Ellison J, Jungblut V, Lavieren HV, Wilson L, Areki F et al. Adapting to pacific island mangrove responses to sea level rise and climate change. Climate Research 2006; 32 (3): 161-176.

Gislason PO, Benediktsson JA, Sveinsson JR. Random Forests for land cover classification. Pattern Recognition Letters 2006; 27 (4): 294-300.

Landis JR, Koch GG. The Measurement of Observer Agreement for Categorical Data. Biometrics 1977; 33: 159-174.

Lima MW, Alves MAMS, Santos MLS, Santo ET, Nunes DM. Influência do ciclo de maré na variação dos parâmetros físicoquímicos no estuário do rio Curuçá, Nordeste Paraense. Boletim Técnico Científico do Cepnor 2014; 14 (1): 09-15.

Loubry D, Prost MT. Estruturas Arquiteturais dos Bosques de Avicennia Germinans e Rhizophora Mangle: Elementos diagnósticos da dinâmica de manguezais das margens do rio Marapanim (Estado do Pará, Brasil). In: Prost MTRC, Mendes AC, editors. Ecossistemas Costeiros: Impactos e Gestão Ambiental. Museu Paraense Emílio Goeldi. Belém: Pará; 2013.

Matias L, Silva MD. Monitoramento e análise da vegetação de manguezal no litoral sul de Alagoas. Journal Of Environmental Analysis And Progress 2017; 2 (3): 312-319.

Mendes AC, Silva MS, Santos VF. Análise do meio físico para gestão ambiental das ilhas de Algodoal e Atalaia (NE do Pará). In: Prost
MTRC, Mendes AC, editors. Ecossistemas Costeiros: Impactos e Gestão Ambiental. Museu Paraense Emílio Goeldi. Belém: Pará; 2013.

Ministério do Meio Ambiente. Shapefile Unidades de Conservação [cited 2019 may. 19]. Available from: https://www.mma.gov.br/ areas-protegidas/cadastro-nacional-de-ucs/.

Mochel FR, Correia MMF, Cutrim MVJ, Ibañez MSR, Azevedo ACG, Oliveira VM et al. Degradação dos manguezais na Ilha de São Luís (MA): Processos Naturais e Impactos Antrópicos. In: Prost MTRC, Mendes AC, editors. Ecossistemas Costeiros: Impactos e Gestão Ambiental. Museu Paraense Emílio Goeldi. Belém: Pará; 2013.

Nascimento Júnior WR, Souza Filho PWM, Proisy C, Lucas RM, Rosenqvist A. Mapping changes in the largest continuous Amazonian mangrove belt using object-based classification of multisensor satellite imagery. Estuarine, Coastal and Shelf Science 2013; 117: 83-93.

Oliveira MVC, Henrique MC. No meio do caminho havia um mangue: impactos socioambientais da estrada Bragança-Ajuruteua, Pará. História, Ciências, Saúde-manguinhos 2018; 25 (2): 497-514.

Pinheiro ES. Sustentabilidade, manguezais e reserva extrativista: Instituições e Atores Sociais nos Municípios de Curuçá e São Caetano de Odivelas [dissertação]. Belém: Universidade Federal do Pará; 2014.

Prost MT, Mendes AC, Faure JF, Berrêdo JF, Sales MEC, Furtado LG et al. Manguezais e estuários da costa paraense: exemplo de estudo multidisciplinar integrado (Marapanim e São Caetano de Odivelas). In: Prost MTRC, Mendes AC, editors. Ecossistemas Costeiros: Impactos e Gestão Ambiental. Museu Paraense Emílio Goeldi. Belém: Pará; 2013.

Ribeiro Júnior MAS, Bastos MNC, Gurgel ESC, Carvalho AV. Valoração do Manguezal do Município de São Caetano de Odivelas - PA. In: Biblioteca do Museu Paraense Emílio Goeldi, editor. Anais Workshop a Ciência na Costa Amazônica, 1., 207, Belém: Pará; 2017.

Rosa MR. Classificação do padrão de ocupação urbana de são paulo utilizando aprendizagem de máquina e Sentinel 2. Revista do Departamento de Geografia 2018; special:15-21.

Rouse W, Haas RH, Schell J A, Deering DW. Monitoring vegetation systems in the great plains with ERTS. In: NASA, editor. Earth Resources Technology Satellite-1 Symposium, Washington; 1973.

Rovai AS, Soriano-Sierra EJ, Pagliosa PR, Cintrón G, SchaefferNovelli Y, Menghini RP et al. Secondary succession impairment in restored mangroves. Wetlands Ecology And Management 2012; 20 (5): 447-459.

Sales JBL, Mehlig U, Nascimento JR, Rodrigues Filho LF, Menezes MPM. Análise estrutural de dois bosques de mangue do rio Cajutuba, município de Marapanim, Pará, Brasil. Bol. Mus. Para. Emilio Goeldi Ciência Naturais 2009; 4 (1): 27-35.

Seixas JAS, Fernandes ME, Silva ES. Análise estrutural da vegetação arbórea dos mangues no Furo Grande, Bragança, Pará. Boletim Museu Paraense Emilio Goeldi Ciências Naturais 2006; 1 (3): 61-69.

Soares MLG. Estrutura vegetal e grau de perturbação dos manguezais da Lagoa da Tijuca, Rio de Janeiro, Brasil. Revista Brasileira de Biologia 1999; 59 (3): 503-515.

Souza Filho PWM. Costa de manguezais de macromaré da Amazônia: cenários morfológicos, mapeamento e quantificação de áreas usando dados de sensores remotos. Revista Brasileira de Geofísica 2005; 23 (4): 427-435. 
Souza Filho PWM. Dinâmica natural e impactos antrópicos no uso de áreas costeiras da planície Bragantina, Nordeste do Pará, Brasil. In: Prost MTRC, Mendes AC, editors. Ecossistemas Costeiros: Impactos e Gestão Ambiental. Museu Paraense Emílio Goeldi. Belém: Pará; 2013.

Spalding M, Blasco F, Field C. Word Mangrove Atlas. Okinawa, Japan: The International Society For Mangrove Ecosystems; 1997.

Teles GC, França CF. Análise da dinâmica de uso e ocupação da terra no Município de São João da Ponta-PA, entre 1984 e 2004. In: Congresso Brasileiro de Geógrafos. Vitória: Espírito Santo; 2014.

Teles GC, Pimentel MAS. A nova perspectiva de Geossistema, proposta por Bertrand, aplicada a bacia hidrográfica do rio Mocajuba - Nordeste Paraense. Boletim Campineiro de Geografia 2015, 5 (2): 381-389.
Thomas N, Lucas R, Bunting P, Hardy A, Rosenqvist A, Simard $\mathrm{M}$. Distribution and drivers of global mangrove forest change 1996-2010 2017; Plos One, 12 (6): e0179302.

Thomas N, Bunting P, Lucas R, Hardy A, Rosenqvist A, Fatoyinbo T. Mapping mangrove extent and change: a globally applicable approach. Remote Sensing 2018; 10 (9): 1466-1485.

Vale JRB, Costa JA, Santos JF, Silva ELS. Análise comparativa de métodos de classificação supervisionada aplicada ao mapeamento da cobertura do solo no município de Medicilândia, Pará. Interespaço: Revista de Geografia e Interdisciplinaridade 2018; 4 (13): 26-44.

Xu H. Modification of normalised difference water index (NDWI) to enhance open water features in remotely sensed imagery. International Journal Of Remote Sensing 2006; 27 (14): 3025-3033. 